Understanding the influence of farmer motivations on changes to soil erosion risk on sites of former serious erosion in the South Downs National Park, UK

J. Boardman ${ }^{1}$, S. Bateman ${ }^{2}$ and S. Seymour ${ }^{2}$

${ }^{1}$ Environmental Change Institute, University of Oxford, OX1 3QY, UK and Department of Environmental and Geographical Science, University of Cape Town, South Africa, ${ }^{2}$ School of Geography University of Nottingham, University Park, Nottingham NG7 2RD, UK

Manuscript accepted on 28 Oct 2016 for publication in Land Use Policy 60 (2017) 298312.

Publisher version accessible at

http://www.sciencedirect.com/science/article/pii/S026483771630446X 


\title{
Understanding the influence of farmer motivations on changes to soil erosion risk on sites of former serious erosion in the South Downs National Park, UK
}

\begin{abstract}
Serious soil erosion occurred in the South Downs National Park, southern England in the years 1982-2006 and details of around 400 sites are contained in a database. In 2010 we revisited 85 of the most serious sites where erosion of $>10 \mathrm{~m}^{3} \mathrm{ha}^{-1} \mathrm{y}^{-1}$ had been recorded in order to assess land use change and any conservation measures undertaken. At $79 \%$ of the sites land use change had resulted in a reduction in the risk of erosion, most notably at 28 sites with a shift to permanent grass from winter cereals. At only $21 \%$ of sites was the risk of erosion unchanged. Twenty two farmers responsible for 66 of the sites were interviewed. Land management practices had changed on all of the fields of interest to this study since the time of the serious erosion events, to those which have the potential to lower soil erosion risk. Sixteen interviewees claimed that erosion was a motivating reason for changing their practices, due to either experiencing on or on- and off-farm impacts firsthand (12), having knowledge or suspicion of serious erosion having occurred on their land prior to their management (three), or having no knowledge of any serious erosion on their land but just wanting to reduce overall erosion risk (one). Amongst the main changes reported are changes of land use from winter cereals to grass or to overwinter stubble which have undoubtedly reduced the risk of erosion. However, some changed practices claimed by farmers, such as along-the-contour-working, earlier sowing and the use of rollers may be of little value. Furthermore, deeper analysis of farmers' motivations regarding changes in land management practices suggests a complex picture in which a range of socio-economic influences come into play over time including financial incentives offered by agrienvironmental schemes which were found to be an important driver of change. Future changes in farming economics may therefore undermine the reduction in erosion risk in the longer term.
\end{abstract}

Keywords: serious soil erosion, farmer motivations, soil conservation, off-site damage, agrienvironment schemes, South Downs National Park, Western Rother valley 


\section{Introduction}

Erosion is widely recognised as as a threat to global soils impacting on their ability to grow crops and maintain a valuable service role such as in the control of flooding (Montgomery, 2007). Freshwater pollution and reservoir sedimentation are two important consequences of unchecked erosion. In this context, numerous publications have addressed the issue of erosion control, or soil conservation e.g. Morgan, 2005; Boardman, 2002. Inextricably linked to this challenge is the problem of understanding farmers' motivations to combat erosion and therefore designing policy frameworks that are likely to yield results. These have been longstanding concerns for academics and policy makers in parts of the world where soil erosion has become an issue. In the global north most early research was undertaken in the USA from the 1950s, with Australia neglected until the 1990s (Sinden and King, 1990: 180) and Europe receiving only limited attention to date (Lahmar, 2010), with a stronger focus instead on Agri-Environment Schemes (AESs) adoption (Wauters et al., 2010). A recent review of studies from across the world of farmers' adoption of conservation agriculture by Knowler and Bradshaw (2007:25) argues, however, that there are "few if any universal variables that regularly explain" why relevant conservation agriculture practices, themselves highly context specific (Lahmar, 2010), have been taken up by farmers. This has led to further calls (Knowler and Bradshaw, 2007; Prager and Posthumus, 2010) for more contextualised studies of the type presented here.

The risk of erosion in the UK is particularly associated with intensive arable cultivation on lowland areas of England and Wales. A combination of erodible soils, slopes, vulnerable crops and a lack of conservation measures has led to erosion being a feature of parts of the east and west Midlands, Somerset, south Devon and chalk and greensand areas of southern England (Evans, 1996; Boardman and Evans 1994, 2006). Two distinct examples are found within the South Downs National Park, both with a history of intensive agriculture and associated problems of runoff and erosion. The South Downs sensu stricto is underlain by chalk and typically the soils are thin rendzinas of the Andover association (Jarvis et al., 1984). The term 'South Downs' is used here in the sense adopted for the recently designated National Park in that it includes an area to the north of the chalk Downs on Lower Greensand soils around Midhurst. Post Second World War the expansion of arable farming, mainly winter wheat, led to an erosion problem on the chalk soils. In contrast, the valley of the Western Rother around the town of Midhurst is underlain by Lower Greensand with intensive arable farming of potatoes, maize, cereals and salad crops on sandy loam soils of the Fyfield 1 and 2, Frilford and the Shirrell Heath 1 associations (Jarvis et al., 1984). The chalky soils of the South Downs are regarded as at moderate risk of erosion whereas the greensand soils are at high risk (Evans, 1990).

Throughout the 1980s and 90s soil erosion was a serious threat on the South Downs, an area which has become widely regarded as a European 'hot spot' for acute events (Boardman, 2003; Verstraeten et al., 2003) (Figure 1). In exceptional years (1982, 1987 and 1990) cases of erosion were widespread and they were accompanied by off-site damage due to muddy flooding of properties and roads (Figures $2 \mathrm{a}$ and $2 \mathrm{~b}$ ). The most recent occurrences were in 
2000 and since then there have been few instances except in the area around Midhurst in the autumn of 2006. During these three decades almost all cases occurred in the months OctoberDecember and the great majority were on land prepared for, or drilled with, winter cereals. The explanation for this pattern is the coincidence of large areas of bare, or nearly bare, ground at the wettest time of the year, with a predominance of winter cereals in the landscape. The lack of cases since 2000 suggests either that the climate has changed or that farmers have changed their land use or their practices. There is little evidence of climate change (e.g. Boardman et al., 2009) but considerable anecdotal and observational evidence of changes in land use. However questions remain as to how extensive land use and practice change has been, what has motivated such changes, and how soil erosion risk is likely to develop in the future. This paper attempts to answer these questions by examining sites of serious erosion, their current land use and the management decisions behind this. Clearly the sites selected are not representative of land use on the South Downs but of sites of serious erosion. However, it is suggested that it is at these sites that farmers could be expected to have responded most to the loss of soil and in some cases to the down-valley muddy flooding that occurred. Therefore the key questions that the paper seeks to address are:

i) How has soil erosion risk changed from 1980s to now and what are the characteristics of this changed risk (including land use change; flood defence structures; changes to farming practices)?

ii) What are the key factors motivating farmers and land managers to change or retain management practices on fields with a history of serious soil erosion and how do these relate to relevant and robust soil conservation practices?

iii) How are soil erosion risk levels likely to develop in the future?

\section{Soil erosion and its management}

The policy context

There is evidence to suggest that soil conservation was neglected as an issue at institutional levels both in Britain and Europe until the 1990s (Environment Agency, 2002; Evans, 2010a; Fullen, 2003). In England evidence of acute 'muddy flooding' problems in the South Downs and concerns over sediment impacts on water quality, both prominent public issues, helped prompt a concerted institutional response to soil erosion from agricultural land and other sources (Boardman, 2002). Despite the status of soil transfer as a form of 'pollution', akin in its acute forms to a water pollution incident, the dominant institutional responses to the control of soil losses from agricultural land have been through voluntary means. There is little evidence of prosecutions by the Environment Agency or its predecessor, the National Rivers Authority, in relation to acute agricultural soil erosion events and a favouring of alternative approaches (Seymour et al., 1999; Environment Agency, 2002). Likewise, while there have been a number of cases where warnings have been issued under the 1980 
Highways Act in relation to mud on public roads, there are few cases of prosecutions in relation to these (Boardman, 1994; Posthumus and Morris, 2010) though Posthumus et al. (2011: 107) recommend the deployment of "prosecution based on liability" as part of a suite of incentives to promote better soil conservation. Private individuals affected by muddy flooding have had some success in pursuing incidents through the civil court system, though compensation for damage has dominated over securing future actions to reduce erosion risk (Environment Agency, 2002; Boardman, 1994; Boardman et al., 2003).

Within Defra, the government department responsible for agriculture and the environment in England, the main approaches have been to enhance advice and agri-environmental support to farmers to help them conserve soils more effectively. The first specialist Code of Good Agricultural Practice for the Protection of Soil was issued in 1998, followed by a series of more detailed advisory packages. However, the tendency has been to approach soil conservation through more prominent measures focused on diffuse water pollution prevention rather than on soils in situ (Posthumus et al., 2011), most notably the Catchment Sensitive Farming Delivery Initiative (CSFDI) established in 2004 primarily to address the requirements of the Water Framework Directive (Defra, 2004). This set out to raise awareness of water pollution, including that related to sediment transfer, and through the Catchment Sensitive Farming Project encouraged voluntary remedial action, in priority catchments, supported by advice and, where appropriate, $50 \%$ capital grants. Recent scheme evaluations highlight good levels of farmer engagement and positive impacts on water quality in these areas, including evidence of reduced sediment transfer (Environment Agency, 2014). Yet soil, unlike water, still has no framing EU Directive. One was proposed in 2006 but withdrawn in 2014, though the same year sustainable soil management was made a target of the Seventh Environment Action Programme (CEC, 2006; Duruiheoma et al., 2015). Soil erosion prevention has also more recently been integrated within the well-established voluntary AES tradition of England under which farmers and land managers receive payments for undertaking a range of environmentally-oriented practices. The early schemes, most notably Environmentally Sensitive Areas (ESAs) (from 1987), had a strong biodiversity and landscape orientation and did not consider issues of soil erosion. However, under the English Environmental Stewardship (ES) scheme, introduced in 2005 (and replaced by Countryside Stewardship in 2015) resource protection measures, including those specific to soils, were incorporated as one of four key priority goals and informed around $50 \%$ of options (e.g. Defra, 2005a; Boatman, et al., 2008: 104). Due to the relative recent introduction of these measures into AESs there has been only limited evaluation of their impacts.

Regulatory measures in relation to soils have focused on cross-compliance provisions brought in following the 2003 Common Agricultural Policy (CAP) reforms. In 2006, Soil Protection Reviews were made compulsory in England under the Good Agricultural and Environmental Condition requirement of cross-compliance and while the need for such reviews was withdrawn in 2015, three new soil cross-compliance measures were introduced (Defra, 2005b; Defra, 2006; HM Treasury and Defra, 2005; Defra, 2015). Under cross- 
compliance, farmers do not receive their Single Payment (from 2015 Basic Payment) production subsidies if they fail to comply with the conditions (with reductions operating on a pro rata basis). However, as the level of such production-based subsidies declines, the economic purchase of cross-compliance on farmer behaviour is likewise understood to reduce (Morgan and Reid, 2008).

Understanding farmer motivations and their influence on soil conservation practices

A substantial body of work has set out to understand what motivates farmers to conserve soils (e.g. Knowler and Bradshaw, 2007), or to engage in state conservation schemes (e.g. Morris and Potter, 1995; Wilson and Hart, 2000; Lastra-Bravo, et al., 2015). These consider a range of push and pull factors and environmental as well as socio-economic elements. Prager and Posthumus (2010) have outlined three paradigms used to identify and account for socioeconomic motivations to conserve soils - the economic constraint paradigm (popular particularly in early US studies), the innovation-diffusion-adoption paradigm (where information is key, based on the work of Rogers (1995)) and the adopter-perception paradigm; frameworks predicated on ideas of social connectivity (e.g. social capital - Sobels et al., 2001) and knowledge cultures (Tsouvalis et al., 2000) might also be added here. All are informed by how farmers themselves understand their soils, particularly vis-à-vis scientific perspectives (Baginetas, 2008; Ingram et al., 2010; Duruiheoma, et al., 2015), and with reference to cultural norms and social symbolism (e.g. Schneider, et al., 2010 and in a wider context, Burton, 2004).

The limited explanatory power of early approaches based on economic and information approaches (see Traore et al., 1998) has led to a wider range of motivational factors being considered (Wauters et al., 2010), embracing personal, socio-cultural, institutional, practical and biophysical as well as business concerns (Prager and Posthumus, 2010) and attention to on- and off-farm aspects.

Conservation agriculture studies have often been deployed in areas where high rates of erosion exist (see Sinden and King, 1990; Smit and Smithers, 1992; Wauters et al., 2010 as examples from Australia, Canada and Belgium respectively). However, views are divided over the motivational impact of serious erosion on farmer uptake of anti-erosion measures. Smit and Smithers' (1992: 7) review of earlier studies by Ervin and Ervin (1982) and Nowak (1987) reports that farmers working land "inherently more susceptible to erosion problems are thought to have a greater propensity to adopt conservation practices". Sinden and King (1990) also found in their New South Wales, Australia, study that in areas of serious soil erosion there are higher levels of uptake of soil conservation measures than in places where erosion is less severe. They argue furthermore that acknowledgement of a soil erosion problem can be related to the percentage of on-farm erosion experienced by the farmer, whereas the adoption of soil conservation measures is related to the intensity of the erosion. Nonetheless, in their overall review Knowler and Bradshaw (2007: 35) report that while "some studies have found the presence of soil erosion and other soil problems on a farm correlates positively with conservation tillage adoption ... farmer awareness of, and concern 
for, soil erosion is probably the more critical factor affecting adoption". Green and Heffernan (1987: 151) in their US-based study argue that problem perception is "influenced more by social and economic factors than by the actual extent of the problem". Furthermore, contrary to their expectations, Smit and Smithers' (1992: 8) own empirical study found "the potential erodibility of farmland was not significantly related to the adoption of conservation practices". The soil erosion literature also considers the influence of the spatial dimensions of erosion impacts on farmer uptake of conservation agriculture, most notably through comparisons of on- and off-farm effects. Smit and Smithers (1992: 8) in their Canadian study in an area of serious on- and off-farm soil erosion impacts, found that those farmers who identified "soil erosion as an agricultural issue, with its on-farm implications for productivity and sustainability" reported they were more likely to adopt conservation practices than those identifying concerns over "water quality - an off-farm problem". The implication they draw is that "off-farm concerns do not provide an impetus for the adoption of soil conservation practices equal to that provided by on-farm concerns" (p.8). However, when serious off-farm impacts are accompanied by prosecution threats there is evidence from Posthumus and Morris' (2010) study in the Parrett catchment of Somerset, UK that they provide a motivation for soil conservation (alongside awareness of on-farm costs of nutrient losses and access to practical advice).

In literature examining farmer motivations to adopt soil conservation measures there has been atendency to regard these as purposeful responses to an erosion problem (e.g. Sinden and King, 1990). However, there are grounds for questioning this view (see Prager and Posthumus, 2010). For example, Duff et al. (1991: 217) found that of the 100 farmers surveyed in their study area of "highly erosion-prone farmland" in south west Ontario, Canada, while most (87) had noticed erosion and $85 \%$ of these had taken some remedial action, only about a third were motivated to do so by soil erosion per se, whereas the rest made changes due to general soil protection and productivity concerns, farm enterprise or production changes. This suggests that farmers adopt anti-erosion measures for reasons beyond specific concerns about soil erosion (Prager and Posthumus, 2010). One of these reasons is the availability of wider agri-environmental scheme support. In this context Knowler and Bradshaw (2007: 36-37) found that four out of the six relevant studies they reviewed highlighted the importance of AESs to adoption of conservation agriculture. The wider literature on entry into agri-environmental schemes likewise suggests a range of motives, beyond concerns prompted by specific environmental issues, informing farmer enrolment (see Wilson and Hart, 2000; Lastra-Bravo et al., 2015).

This literature also provides a conceptual framework which can be used for understanding motivations to conserve soils in terms of 'passive' and 'active' adoption (see Morris and Potter, 1995). Passive adoption characterises participation prompted by "pragmatic reasons rather than for conservation" in its own right (Wilson and Hart, 2000: 2170) with financial motivations to the fore and few barriers identified in terms of management adjustments (Morris and Potter, 1995). Once financial incentives (such as AES payments are withdrawn, such passive adopters are likely to revert to past practices. By contrast active adoption is 
more typically motivated by environmental and altruistic concerns (Morris and Potter, 1995). While AES participation levels have frequently been high in England and Wales, there has been a tendency for passive or adventitious forms of participation to be dominant (see Morris and Potter, 1995) and this was discovered strongly to be the case in a study of the South Downs ESA by Lobley and Potter (1998). Likewise, in a Belgian soil erosion context Wauters et al. (2010) found that AESs are not currently helping "in improving farmers' attitudes and internal motivations" to conserve soils and concluded that "their effect is unlikely to sustain after the schemes' termination".

While particular studies place more emphasis on particular motivating factors informing soil conservation, socio-economics (e.g. Green and Heffernan, 1987), farmer attitudes (e.g. Wauters et al., 2010; Ryan et al., 2003) social symbolism (e.g. Schneider et al., 2010) and institutional support, an increasing number argue for an interdependency of prompts (Sinden and King, 1990; Smit and Smithers, 1992): "it is always a mix of personal, socio-cultural, economic, institutional and even environmental variables that explain [soil conservation adoption] behaviour" (Prager and Posthumus, 2010: 217; Posthumus et al., 2011). This paper draws on the ideas of passive and active adopters used in the literature on agri-environmental scheme participation to understand the relative motivational importance to farmers of finance and pragmatism, environmental and altruistic concerns and the experience of serious soil erosion when undertaking soil conservation measures.

\section{Methodology}

A dual strategy of soil risk assessment and the evaluation of motivations for changes in farmers' behaviour has been deployed in this study, using a recognised classification and semi-structured interviews respectively. From a database of around 400 cases of erosion on the South Downs and in the Midhurst area (1982-2006), 85 fields were selected as 'serious' which was taken to be $>10 \mathrm{~m}^{3} \mathrm{ha}^{-1} \mathrm{y}^{-1}$. In most cases (68), soil loss from the field was estimated by measurement of volumes lost from rills and gullies (Evans and Boardman 1994). In a minority of cases (17, a fifth) the site was included on the basis of observations and photographs, indicating clear signs of serious erosion, rather than measurement. At 47 sites $(55 \%)$ off-site impacts (beyond the field) were recorded. Several sites exceeded the soil loss threshold for inclusion in more than one year. The distribution of sites by time period was as follows: pre-1987 15; 1987 32; 1989 5; 1990 10; 1993-2006 23. The Midhurst sites were all from 2006 (see Figure 3).

All 85 sites were visited on either 18 and 19 October or 18 November 2010 and land use and any soil conservation or anti-runoff measures being undertaken were recorded. The autumn period was chosen so that a comparison with the year of erosion could be made. Details of erosion are contained in previous publications and reports, specifically Boardman and Robinson (1985), Boardman (1988), Boardman (1990), Boardman (2001), Boardman (2003), Boardman and Evans (1991), Evans and Boardman (2003), Boardman et al. (2009) and Evans 
(2010b). We assess the effect of land use change in terms of a reduced risk of erosion or a continuation of a similar level of risk. There were no cases of an increase in risk e.g. from winter cereals to maize. The concept of risk of erosion associated with a crop/land use is based on observation and on advice contained in Defra (2005b) where crops are listed according to their perceived risk.

The aim was to interview all current farmers of the 85 fields that were re-surveyed in October and November 2010 to explore their current and proposed management practices and the motivations behind them, including the importance of and extent to which they had reacted to experiencing serious erosion events on their land. Farmers were also asked about the role of AESs in motivating and facilitating their land management as the area has a long history of scheme availability. In order to identify the current farmers of these fields a number of sources were used which were: existing research team knowledge, other farmers, a land agent, Brighton and Hove City Council, Eastbourne Borough Council and the National Trust. Twenty five farmers were identified, 22 of whom agreed to be interviewed. This was an acceptance rate of $88 \%$. Only one farmer refused to take part and two farmers could not be contacted despite repeated attempts. Semi-structured telephone interviews were carried out with these 22 farmers between February and July 2011. Semi-structured interviews allow a more wide-ranging discussion, producing a deeper picture than questionnaires and were thus considered a suitable method for this study (Silverman, 1993, p. 15). Interviews lasted between 10 minutes and one and a half hours with the majority lasting around half an hour. The use of telephone-based interviews was chosen due to cost constraints but the style of a semi-structured interview was retained. A large majority (66 or 78\%) of the fields of interest were covered by the interviews. Most of these (59 or $89 \%$ ) lay within the South Downs ESA set up in 1987, the exceptions being seven fields (managed by two farmers) which were in the Midhurst area (Figure 1). The existence of an ESA designation for the majority of the area was identified as a key potential influence on land use change.

The main interview themes and specific questions asked are shown in Table 1. As some erosion events happened a considerable time ago, it was expected that a number of interviewees would not necessarily have been farming these fields at the time of the erosion. Therefore they were asked how long they had been managing the land in question. It was still considered important to explore the extent to which current farmers were managing these fields in a soil conservation context, and the degree to which any knowledge of these previous events had impacted upon their current soil management practices in these fields.

Sixteen interviewees were the main, joint or only farmer and one was largely hands off but had a strong input into how the farm was managed. Four were farm managers but were neither the owner nor the tenant, whist another was an agent for Eastbourne Borough Council. In total, seven interviewees owned their entire holding, ten were tenants and four owned some of their holding and rented the rest. One interviewee, who was an agent for the local council, said the field he managed was owned by the local council and was managed via grazing licences, being rented to local farmers. A large majority of the interviewees (17 or $77 \%$ ) were aged 45 or over, with only one being under 35 . The farm types that made up the 
interview sample and how they compare to commercial holdings sampled for the 2010 June Census Data in the South Downs National Park are shown in Table 2. The table shows that the farm types in this sample are not representative of the holdings sampled for the June Census Data, with a much higher proportion of mixed farms in our sample.

\section{Soil erosion risk change and its characteristics}

Of the 85 sites where serious erosion had occurred 67 (79\%) are assessed as being at a lower risk of erosion in the 2010-11 growing season based on their land use . Of these, the principal shifts in land use were from winter cereals to permanent grass (28), and from land prepared for winter cereals (ploughed, harrowed or cultivated), to permanent grass (six); from winter cereals to oil seed rape (six) and from land prepared for winter cereals (ploughed, harrowed or cultivated), to oil seed rape (seven); and from winter cereals to stubble (eight). The risk of erosion remained the same at $18(21 \%)$ sites and this was mainly due to a continuation of winter cereal cultivation at 12 sites.

There were few obvious robust soil conservation measures. At nine sites fields had been reduced in size and at a further two an adequate downslope grass border had been introduced. One field had been direct drilled with turnips into cereal stubble.

At a number of sites in this sample the response to serious erosion and off-site damage has been to build small dams. These were at Sompting, Rottingdean, Bevendean, Ovingdean and Breaky Bottom (see Figure 1). These represent in some cases an 'emergency response' to flooding and in others a long-term response. Dam building at Highdown, Lewes has been shown to be of dubious value and, in the long-term, expensive, unsafe and probably ineffective (Stammers and Boardman, 1984). At both Breaky Bottom and Rottingdean, temporary emergency dams failed almost immediately but at the latter site were replaced by more sturdy structures together with land-use change (see above). Similarly, at Sompting and Ovingdean, land use change was instigated together with dams. At Bevendean substantial dams were built to replace smaller ones but without land-use change (Figure 4). At Bevendean and Rottingdean the dams were constructed and paid for by the local council in order to protect houses; at other sites dams were built by the farmers. Of the 85 fields in the field survey, 19 (23\%) have had dams constructed down valley of them. Not all are likely to be effective especially with regard to maximal predicted flows. While not affecting erosion on the fields they do offer some protection to neighbours. What we can conclude is that the dams were part of a response to the experience of down-valley flooding but are likely to be more effective when combined with land use change (cf Boardman and Vandaele, 2010). This topic is explored more fully in Boardman et al. (2003).

The interviews revealed that land management practices had changed on all of the fields of interest to this study to some degree since the serious erosion event(s) (Table 3), and the majority of these practices can in theory, reduce erosion risk, although as explored later in the paper, not all practices had been changed for erosion-related reasons. Only 13 out of the 22 
interviewees were managing the fields at the time of the erosion events observed by the first author and therefore some arable reversion and earthwork construction had been undertaken under previous management.

The most common management changes were those related to change of land use, namely arable reversion to permanent grassland and overwinter stubble. Arable reversion was reported by 18 farmers ( 28 fields or $42 \%$ of those covered by interviews). Another popular land use change was the use of overwinter stubble (20 fields or $30 \%$, seven farmers). Only two farmers said they had introduced buffer strips (six fields) and only one farmer, who also used buffer strips, had introduced beetle banks (five fields) on vulnerable fields,. This may be due to farmer scepticism over their efficacy in the area. One farmer, who himself had buffer strips, contested their effectiveness in stopping erosion, commenting that "if you've got a soil erosion problem, it comes off the whole field and it'll go straight over a buffer strip, it won't hold it back" (Farmer 2). Regarding changes in cultivation techniques, working across the slope was the practice most referred to (34 fields or 52\%, nine farmers) although eight of the nine farmers who used this practice commented on its limitations. One farmer commented that “...I'm sure [ploughing acrossways] wouldn't stop any real runoff if we had the real torrential downpours that we had in the past" (Farmer 10). A common view was that it was often just not practical or safe either due to the steepness of slopes or if a field has various angles within it. Other notable management changes were the introduction of minimum tillage (20 fields or 30\%, 3 farmers) and a consideration of the timing of operations ( 24 fields or 33\%, 6 farmers). Another significant management adjustmentinvolved a change in cropping patterns (20 fields or $23 \%$, four farmers). This involved either dividing individual fields across the slope and planting these divisions with different crops, e.g. the upper half in a spring crop and the lower half in a winter crop, in order to reduce the effects of any erosion, and/or ensuring there was not a continuous run of the same crop in adjacent fields down a slope.

\section{Farmer motivations to address soil erosion risk}

A range of factors were found to be important in motivating farmers to introduce land management practices which have the potential to lower soil erosion risk. Table 4 highlights that farmers and land managers often gave a combination of motivating reasons for changing their practices.

Out of the 22 land managers that were interviewed 16 claimed erosion had been a motivating factor in their decision to change one or more of their practices. A large majority of these farmers (12) had experienced on or on-and off-farm impacts firsthand and had changed their practices, albeit to different degrees, whilst three had second hand knowledge or suspicion of serious erosion having occurred on their land prior to their management. One farmer had no knowledge of serious erosion occurring on his land and just wanted to reduce erosion risk. For the remaining six farmers, who said they had not experienced any serious erosion or impacts, reasons other than erosion were the catalyst for them to change their practices. 
Indeed Table 4 shows that additional factors were also of relevance to those farmers who claimed erosion was a reason for them to change their practices.

The twelve farmers who said they had been motivated to change their practices due to experiencing erosion impacts firsthand, had all experienced on-farm impacts as a result of erosion on their land (31 fields or 47\%), with seven of these farmers also experiencing offfarm impacts (20 fields or 30\%). All twelve of these farmers claimed that as a result of these impacts occurring, they had been motivated to change one or more of their land management practices on one or more of their fields (37 fields in total or 56\%) (Table 5).

Of the seven farmers who had experienced both on and off-farm impacts, three had only introduced a single practice to reduce the risk of erosion (Farmer 3: timing of operations; Farmer 9: working across the slope; Farmer 12: earthworks). However, the remaining four farmers had been particularly proactive and had introduced a suite of practices specifically to reduce erosion risk (Farmer 2: ten practices; Farmer 4: four practices; Farmer 7: five practices; Farmer 8: five practices). The combination of motivational factors informing the changes made by these four farmers are outlined as a case study later in this section.

It is worth noting that even second hand knowledge of, or suspicion that on- and/or off-farm impacts resulting from erosion had occurred on their fields prior to their management, was a motivation for some farmers to change their management practices to reduce erosion risk. There were nine interviewees who farmed thirteen fields of interest to this study, who were not managing these fields at the time of the erosion events. However, three of these farmers (seven fields) had second hand knowledge of on- and/or off-farm impacts resulting from erosion on their fields prior to their management as they lived in the local area at the time of the erosion events. Three other farmers (six fields) suspected serious erosion had occurred on the land they managed due to the presence of earthworks (two farmers/4 fields) or rills in a permanent grassland field (one farmer/1 field).

Out of the six farmers who had second hand knowledge of, or suspected serious erosion had occurred in the past, three had changed their practices. All three farmers practiced working across the slope (four fields) one of whom (one field) had also introduced overwinter stubble. One farmer considered the timing of operations on two fields whilst another had changed from a concrete roller to a ring roller to reduce compaction on two fields. The remaining three farmers with second hand knowledge or suspicion of erosion impacts on three of their fields did not undertake any practices specifically for reducing erosion risk. All of these fields were in permanent grass, having undergone arable reversion under previous management.

Three farmers were not managing three fields of interest to this study at the time of the erosion events and were not aware of any erosion or impacts having occurred on these fields in the past. Of these only one claimed to be undertaking any practices for reducing erosion risk, having changed his roller to one designed to reduce soil movement due to rain splash. He stated he would not have made this change if the opportunity to buy the roller cheaply from a neighbour had not arisen. 
The economic incentives offered by AESs, especially the ESA scheme and Entry Level Stewardship/Higher Level Stewardship (ELS/HLS) schemes, have been an important driver for change with regard to land management practices. In over half (59\% or 39) of all the seriously eroded fields managed by interviewees, one or more practices were carried out under an AES, and for over two thirds of these fields ( 26 or 67\%) farmers commented that they joined the schemes principally for financial reasons. One, who argued that his agent said he' $d$ be daft not to enter the scheme, described the payment for arable reversion of his field as "manna from heaven" (Farmer 1). Arable reversion was the most common practice carried out under the schemes (24 fields), accounting for $86 \%$ of cases of this reported in the whole interview sample.

However, out of the eighteen farmers (28 fields) that had undertaken arable reversion, only eight said that reducing erosion risk was a reason for doing it (on 13 fields), all of which had been carried out under either ESA, HLS or ELS. AES subsidies also funded the use of overwinter stubble on 16 fields, over three quarters $(80 \%)$ of the cases reported in the interview sample. For 15 of these fields, reducing erosion risk was the sole or joint reason for undertaking this practice. Beetle banks and buffer strips were subsidised as part of AESs on five and four fields respectively.

Whilst financial incentives were a major reason why farmers undertook arable reversion, other reasons also cited included logistics (outlying, isolated fields), an easy/profitable answer to managing poor/difficult land, wanting more grass on the farm for livestock, public access, and having a lack of infrastructure for arable farming. Reasons for arable reversion were sometimes cited in combination, with one farmer saying that although the financial incentives on offer were a major driver, arable reversion was "the answer to lots of other problems" (Farmer 1).

Field enrolment into arable reversion through the ESA scheme (the dominant measure adopted for erosion vulnerable fields) seems to be clustered into two main phases: 1987-early 1990s (seven fields) and 2000-2003 (nine fields, with large buffers in a further five). First time AES enrolment into the ELS scheme dates from 2005-2006 (ten fields mainly using the overwinter stubble option) and for HLS 2006-2009 (nine fields mainly using overwinter stubble with some arable reversion (two fields), buffers and beetle banks). This positions AESs as central funding mechanisms for key land use changes which have reduced erosion risk in the South Downs, although in most cases of arable reversion, countering soil erosion was not a reason for undertaking this practice.

In the case of just over a fifth (14 or $21 \%$ ) of fields covered by the interviews, land managers were compelled to undertake changes to the management of fields at high risk of erosion. Clauses in tenancy agreements set by landlords (the local council or the National Trust) were the reason why arable reversion had taken place on four fields by three farmers (one interviewee and two previous land managers). Past, serious erosion was the reason why one field could not be ploughed again and was a minor factor for similar restrictions on another field. Public access and landscape value were the main drivers for why landlords insisted on 
arable reversion on three of the four fields. Another farmer commented that he had been forced to change his practices on 10 fields in line with restrictions set by his insurance company due to serious erosion and off-site flooding events in the past. In this case, the farmer was not allowed to grow winter wheat on these fields but instead could only grow crops that were sown earlier in the year such as spring sown crops or winter oil seed rape. He had also introduced direct drilling of some fields.

In a few other cases there is evidence of changed practices linked to a desire to wind down farming practices due to farmer or landlord interests. Three aging farmers (managing three erosion-prone fields) reported de-intensifying their management, all through the use of AESs. A further farmer (managing two fields) reported a shift to less intensive mixed farming due to a change in ownership of the land, while another (managing one field) had moved to a more mixed regime for economic reasons, linked to cereal and machinery prices, and had made use of the ESA and ELS schemes to do this.

\section{Case studies}

To understand further how motivations often work in combination the section below outlines the cases of four farmers who had experienced serious erosion resulting in soil and/or water on others' property, roads or in rivers in addition to rills/gullies on their own land. These farmers highlighted the seriousness of the erosion events experienced. Some gave graphic descriptions of "tremendous erosion" which left "a hideous mess" (Farmer 2) and "filth and mud" in houses down the valley (Farmer 12). One reported how erosion from his land had "flooded a neighbour twice" (Farmer 8) whilst another noted rill erosion which "ran out onto the road" (Farmer 4).

These personal experiences of erosion were strong motivations for the four farmers to change their farming practices by introducing a landscape-scale farming approach to their management of 20 erosion prone fields. This involved a change in cropping patterns to try and break up any future flows of runoff and erosion. Farmers spoke of having "reacted and are doing what is necessary" (Farmer 2) and of trying to "adapt... to minimise the [erosion] risk" (Farmer 4). Farmer 2 is a case in point. On the night he took over the management of five fields in October 2006, they eroded badly due to the fact that the previous farmer had just harvested potatoes which were grown on a large block of sloping fields. That Farmer 2 was the owner-occupier of the farm next door, and his father before him, meant he had great knowledge of the wider landscape and was able to use this knowledge to transform the rented land, stating that "just from farming next door all my life and my father before me, where we have a rotation with grass and cattle as well as the arable crops, ...I know what the farm can be like and this farm ... was a million miles away from it". While he had entered the ELS scheme "as soon as he could" in the following year, and had reverted a small area of one vulnerable field (using the field corner option), with overwinter stubble as an option on others, he was personally motivated to farm "across the slope", producing a "patchwork of crops", with widespread use of overwinter stubble (subsidised by ELS) and stubble turnips (not funded via ELS). Farmer 7 had experienced a serious off-farm erosion event in the 
1980s. Prompting from a farming interest many kilometres lower down the valley, led him to walk down from his farm to the houses affected by muddy flooding and realise that a landslip on his cereal land had initiated the problem. In response he used agri-environmental schemes to help "break ... up the monoculture of cereals" on his 728 hectare farm, splitting up around 69 hectares of "blank arable" with two large permanent grass strips under the arable reversion measures of the ESA scheme. Another farmer from this group (Farmer 8) was partly compelled by the farm's insurance company to change from planting winter wheat in a valley where previous erosion from fields of this crop had inundated a neighbour's property twice, to only planting spring cereal or winter rape. However, he had extended this thinking to instigate broader changes so "in that whole valley there is a split of cropping" to ensure there were not long slopes all in the same crop as well as areas of strategically placed arable reversion and buffer strips to break up any flows of erosion. Agri-environmental schemes played a role in this landscape-scale, patchwork farming approach as all four farmers used ELS or HLS to fund field corner arable reversion, overwinter stubble, buffer strips and beetle banks, or the ESA scheme to create areas of permanent grassland strategically placed to reduce erosion risk (Farmers 7 and 8). Farmer 7 for example, stated that financial incentives from AESs were an important factor in his decision to join these schemes, saying he felt it was "crazy not to take it [ESA payment] if it's there", highlighting the importance of economic considerations even for farmers who are strongly motivated to farm in an environmentally friendly way. However, financial incentives under AES were not the only reason for changing practices. The need for the practices to fit with their farming policy and existing farming system was also important. Farmer 4 who used overwinter stubble under ELS chose this option due to its fit with his farming policy of wanting to continue in arable production, but with a reduced erosion risk, so he had to find ways to do this. However, the limited effectiveness of this practice for reducing erosion risk on his farm was clear when he commented that "We move 15 hectares [of overwinter stubble] around the farm but obviously you can't target a particularly steep field and leave it as overwinter stubble every year because of the rotation". Likewise Farmer 7, who, as previously noted, had used several HLS options plus the ESA scheme to break up areas of arable monoculture said that he had undertaken these practices for the combined reasons of fitting with his farming policies of reducing erosion, introducing more of a crop rotation, enhancing nature conservation, particularly bird life on the farm, together with the financial incentives on offer "A lot of things are encouraged, I don't say initiated by the HLS or the grant schemes, but when you're working out your policies you look at the grant schemes and if they fit with your policy then it's an incentive to do something about it. So the grants that are available encourage the things we are now doing”. However, Farmer 2 said he would probably have changed his cropping patterns without the incentive of AESs, arguing that it was likely that he would have grassed down the field corner and used overwinter stubble without the financial lure of ELS because he knew how effective the measures were in countering erosion. 


\section{Projected changes to soil erosion risk levels in the future}

While we have found an overall reduction in soil erosion risk on past sites of the most serious erosion cases, the reasons for these changes suggest that some may be vulnerable to reversal. However, this seems less so in the short term. On 24 (86\%) of the 28 fields where arable reversion had been undertaken the farmers planned to keep this in place for at least five more years, and aimed to keep 19 of these fields in arable reversion until 2019 or beyond (68\% of all arable reversion fields). At the other end of the spectrum three farmers had definite plans to revert all or part of four of their previously eroded fields (14\% of all arable reversion fields) back to arable within five years, whilst two other farmers would consider doing so on two fields if future conditions were right.

The influence of the end of AES agreements on farmers' future land use decisions was variable. For seven farmers managing eight fields which had undergone arable reversion under an AES, the end of AES agreements did not have a significant bearing on their future management plans. Four fields were regarded by the interviewees to be permanent arable reversions due to tenancy restrictions. Another farmer who no longer had any arable infrastructure said it made sense for his arable reversion field to stay in grass permanently whilst another said he would keep the field corner in grass permanently, with or without a scheme. One elderly farmer was winding down his farming operation, focusing more on nature conservation and had no plans to bring an area of arable reversion back into production saying "it was too steep to do anything with. Better to go down the environmental route to protect the wildlife" (Farmer 15). A farmer with a field in a 20 year Habitat Scheme which runs out in 2020, said he had entered this field into the scheme due to urbanisation problems (motorbikes, fires, stolen cars, people), saying it had been done for peace of mind as these issues caused less damage with the field in grass, and he had no plans to bring it back into arable production.

Two farmers were keen to keep their land in arable reversion beyond the end of long-term current agreements ending in 2019, provided there were suitable schemes available at the time with one of these farmers stating that they would keep the arable reversion in the HLS or similar scheme "[for] as long as they'll have us" (Farmer 8). However, the implication is that they would reconsider management if no such schemes were available.

Three farmers had definite plans to bring arable reversion fields back into production in the next four years. One farmer planned to plough up to half of his field later in 2011 when his ESA agreement was due to expire. This farmer believed that this half of the field was less vulnerable to erosion and unlikely to erode again due to "no real gradient" (Farmer 21) and thought that erosion "doesn't really need to be taken into account". Likewise another farmer planned to bring two arable reversion fields back into production in 2012 at the end of his ESA agreement. A third farmer planned to plough up one field in 2015 when his ESA agreement was due to run out "unless arable prices completely collapse" (Farmer 10). Two other farmers said they would consider bringing arable reversion fields back into production if conditions were right. One said that although he was happy to stay in the HLS scheme for 
the duration of his agreement (until 2019), he may not enrol in another scheme after this if world demand for food continues to rise as he felt it was his duty as a farmer to produce food. The other farmer whilst not having any definite plans to bring his field back into arable production before the end of the full term of his HLS agreement in 2020, did not rule this out. He stated that "We have a lot of sheep and the prices of sheep is going up...I think we will stay in it for the moment" (Farmer 9) but he did not rule out exiting the scheme half way through, in 2015, if he felt it made financial sense to do so.

Four fields managed by two farmers had been reverted to grassland outside of an AES scheme and the interviewees had no plans to bring these fields back into production. Two fields were subjected to restrictions by the local council who owned the land whilst the other two fields had been grassed down by the tenant "off his own back" (Farmer 12) to provide more grazing for livestock. This interviewee said it was unlikely that these fields would revert back to arable for the remainder of the tenancy which runs out in 2021.

With regard to other soil management practices farmers planned to keep overwinter stubble (16 of 20 fields) for at least five more years, and on ten of these fields until 2019/2020. The overwinter stubble on all 16 of these fields was undertaken under an AES and farmers were happy to keep the stubble option in place for the duration of the schemes. Only one farmer said he would retain overwinter stubble without the incentive of an AES as he said that he knew how good they were at reducing erosion risk. Farmers planned to keep all of the beetle banks (five fields) and buffer strips (six fields) for at least five years, with one farmer happy to keep his beetle banks (five fields) and buffer strips (four fields) in place for at least the duration of his HLS scheme which ends in 2019.

\section{Discussion}

There are inherent dangers in taking two separate years to look at a before and after effect. What one could end up with are two 'snapshots in time' unrepresentative of longer periods. However, the focus of the research is to examine, in the context of fields which have experienced serious erosion, if and why a farmer or land manager has subsequently changed his or her practices. The main problem is the arbitrary selection of the autumn of 2010 for a comparison. However, evidence from the interviews suggests that in relation to the vast majority of the fields (57 out of 66) farmers reported that the land use of the 2010-11 season was typical of the way the fields had been managed in the past few years. The first author's personal experience of the wider survey area also supports that land use in the survey year was reasonably representative of preceding years with perhaps increasing amounts of oil seed rape in the last decade.

Another bias in the data is that at 10 sites in Rottingdean on the edge of Brighton very serious erosion and extensive flooding was suffered by people in the adjacent housing estate in 1987 (Boardman, 1988). These fields have reverted to permanent grass as a result of a deal between the owner, Brighton and Hove City Council, and the farmer who rents the fields: the 
rent was reduced in return for a reduction by $50 \%$ in the annual area of winter cereals (Robinson and Blackman, 1990). This constitutes an institutional as well as a personal response to soil erosion. While the land manager at this site did not take part in the survey, a small number of those who did (four) were also subject to similar institutional pressure to change practices on land vulnerable to erosion. However, in three sites this was due to prompts other than erosion prevention (see above).

This study has revealed that most farmers appear to be undertaking one or more practices that have the potential to reduce erosion risk on the fields of interest to this study. In line with current understandings in the field we found a range of factors - economic, practical, personal, social, institutional and biophysical - influencing farmers' past and proposed future land management strategies on land with a history of serious soil erosion, often in quite complex ways (Prager and Posthumus, 2010). That soil erosion risk had reduced significantly on land associated with serious soil erosion at face value suggests this experience is a major prompt to action supporting wider literature which makes this argument (e.g. Sinden and King, 1990). Farmers who have experienced soil erosion at close quarters are motivated by the threat of such events to their reputations as good farmers and by a sense of responsibility to neighbours. However, deeper analysis of farmers' motivations shows a more complex picture in which a range of socio-economic concerns come into play over time and which is significantly impacted by the long term presence of AESs in the area.

While some farmers explicitly highlight how their experience of serious erosion contributed to 'problem' recognition and subsequent action, the process of land use change was often lengthy and supported in particular by the financial compensation opportunities provided by AESs. The timings of farmer entry into AESs suggest the coincidence of the financial incentives provided in a context of reduced cereal prices to have been a greater influence on arable reversion in particular than the dates of serious erosion events, with a number of farmers undertaking 'interim' and less robust practice measures (such as contour working or discing) before making such a decision.

The sometimes considerable delay between the erosion events and undertaking arable reversion noted above is probably due partly to the fact that when it comes to more radical land management changes such as arable reversion, farmers in this study appeared to be mainly financially motivated, reacting to AES drivers and grain prices. Indeed the identified phases of entry into AESs may relate as much to early interest at the instigation of the ESA, and to low arable profitability (see Winter, 2000), the launch of ES and the rush to enrol in HLS before the money was spent (Morgan and Reid, 2008), as they do to concerns to prevent erosion.

A minority of farmers (four) seem to have been persuaded to change management more by coercion from landlords and insurers than by a view of serious erosion as a farming problem. Still others have made management changes which reduce soil erosion risk for reasons other than identification of a soil erosion problem on their farm and a purposeful decision to resolve it. Such actions were again mainly facilitated by entry into AESs. Most who entered 
AESs did so mainly due to the payments on offer, in a general context of depressed cereal prices, for measures which could be accommodated within their existing farming system and business rationale, a trend also found in the wider AES scheme context by Wilson and Hart (2000). This suggests the importance of financial and farm enterprise-based motivations. Only a few (three) undertook soil conservation practices within AESs due to a desire to wind down their businesses as they were aging with no successors, a trend, identified by Potter and Lobley (1992) as an important motivator for engagement in more demanding AES measures in England. Furthermore, in many cases of ESA enrolment in particular, the fields were entered to satisfy environmental priorities other than soil erosion, most notably biodiversity, landscape and access imperatives, the main objectives of the South Downs scheme being focused on the nature conservation value of the chalk grassland (see Lobley and Potter, 1998). This suggests a predominantly passive adoption pattern for AES measures on erosionprone land in the South Downs and a higher level of 'incidental' adoption of soil conservation measures than has been highlighted in many previous soil erosion studies. There is limited wider evidence of changed attitudes and motivations through involvement in such schemes and this casts doubt on the retention of practices if schemes close (see Wauters et al. 2010; Prager and Posthumus, 2010), though other less purposeful prompts may also intervene (such as enterprise change or the changed economics and cultural acceptance of no-till approaches).

Only a minority of farmers stressed conservation values as important reasons for adopting soil conservation practices (counter Duff et al., 1991 and Ryan et al., 2003). In terms of spatial awareness, our findings generally support those reported by Ingram et al. (2010, in relation to Mathieu's French study), that most farmers lack awareness of the wider erosiongenerating processes beyond their farms, focusing instead on risks on their own properties, although there were some notable exceptions. The majority of farmers do not think at a landscape scale with regard to erosion risk, with only a small minority employing a wider spatial erosion strategy with regard to cropping patterns, ensuring that there are no swathes of the same crop in the same field, valley or vicinity. Such responses link to a more active mode of farmer engagement with agri-environmentalism, one in which a farmer's creativity finds an outlet in achieving both good crops and soil protection (see Burton, et al., 2008). This landscape-scale thinking is important in an erosion context, as it has been shown elsewhere on the South Downs that connectivity of fields can result in continuous flow of muddy runoff, the longest of which was measured at over $8 \mathrm{~km}$ in the Sompting catchment, West Sussex (Evans and Boardman, 2003).

Indeed closer inspection of farmer motivations and practices makes it clear that they could be doing more to reduce the risk of more serious erosion events occurring on these fields. It has been noted through personal observation by the first author, that some practices which farmers have been encouraged to employ to reduce erosion risk, and which this study suggests they are using, such as early planting of winter cereals, buffer strips, working across slopes and rolling using a ring roller, are not always effective if there is a large amount of rainfall. Early planting (e.g. mid-September) is quite ineffective if heavy rain occurs in early 
October: the two major erosion events of the last 30 years have occurred on 7 October 1987 and 11 October 2000 (Boardman and Favis-Mortlock, 2014). Buffer strips can be overwhelmed by runoff (see Figure 5) and do little to limit on-site erosion despite being well publicised anti-erosion measures (Natural England, 2010; Rural Payments Agency \& Defra, 2009). Working across the slope may only be effective for small rainfall events, and may actually exacerbate erosion in some cases, for example where runoff is fed into topographic depressions or where potato ridges are overtopped by ponded runoff. Rolling can encourage erosion on the South Downs soils and changing to ring rollers, which two farmers had done, is only moderately effective and would not stop severe erosion from happening. Farmers were advised against the practice of rolling winter cereals as early as 1988: 'Do not roll in the autumn'( Marks, 1988). The limitations of these practices which are outlined here were recognised by some farmers and may indeed be working against their adoption and that of more robust measures.

Agri-environmental schemes are set to continue, but the new Countryside Stewardship scheme (from 2015) promises to be more demanding and less popular, driven in part by a more limited public purse. These AES changes, and long term trends of increasing world demand for food, combined with the UK's promotion of 'sustainable intensification' (Franks, 2014), may well make continued engagement with more demanding measures such as arable reversion less likely in the longer term, especially in cases where multi-functional benefits beyond those of soil conservation - are limited. The South Downs may be hit harder than other areas due to a feeling that a proportion of the land reverted to grassland under the ESA scheme has not delivered the expected biodiversity gains central to the original scheme due to insufficiently rigorous targeting (Burnside et al., 2002). Instead, measures which allow continued arable production, such as overwinter stubble and spring cropping, are likely to be favoured by farmers and agricultural policy makers alike. On the contrary, rises in sheep prices in 2011 and lower than anticipated wheat prices from 2012 helped bolster mixed farming in the area (EBLEX, 2011; AHDB, 2015). Emerging UK policy imperatives linked to 'sustainable intensification' (Government Office for Science, 2011; Franks, 2014) would seem to clash with policy initiatives of the last two decades which have encouraged extensification, diversification and sustainable stable production and it is likely that farmers' role as food producers will be reinvigorated.

\section{Conclusion}

The amount of land use change on fields which have experienced serious erosion in the past has been impressive and that which has taken place has reduced the risk of erosion mainly by replacing winter cereals either with permanent grass or over winter stubble. A series of other 'soil conservation measures' instigated by farmers are of more questionable value. At several sites, some of which are included in the interviewed farmer sample, small dams, with or without land use change, have reduced the risk of off-site flooding. The interviews reveal that all farmers who had experienced soil erosion directly cited this as a motivating factor for 
practice change and had made changes to their management, albeit to different degrees, and that while 'doing the right thing' and challenges to farming reputations in the face of soil loss and damage to neighbours are important motivations they are not generally sufficient on their own to drive practice change. In particular our finding that there have usually been delays in responding to serious soil erosion events suggests a more complex series of socio-economic motivating factors are at work, with the availability of financial incentives from agrienvironment schemes in a period of lower wheat prices particularly important. It also suggests that the majority of farmers in our study are more akin to Morris and Potter's (1995) passive adopters of AESs rather than being active adopters of soil conservation techniques.

The danger of course is that with any changes to AES subsidy levels and wider farm economics the incentive to revert to land uses that increase the risk of soil erosion and flooding will return. Increasing the use of means to compel farmers to take action to conserve soils, particularly where on-farm impacts are experienced, would likely need to be strengthened if the financial incentives to do so voluntarily reduce (see Posthumus, et al., 2011). A complementary policy, more in keeping with current voluntary approaches, would be to encourage farmers to integrate soil conservation further into their farming practice. While this would require a stronger focus on in situ soil management (see Posthumus, et al. 2011) it would be supported by making farm-specific advice deployed in CSF zones available in erosion-prone areas. Furthermore, as soil erosion prevention also often requires thinking beyond the boundary of the farm, more targeted use of collective AES measures would be appropriate (Emery and Franks, 2012). This would have the potential to extend the most innovative soil conservation solutions found in our South Downs study, those based on landscape-scale thinking, whereby farmers split up large blocks of the same crop, or subdivided fields and planted different crops. There are signs that this is a successful way of continuing arable farming in a style which actively incorporates soil conservation into the farming system, and which works with farmers' social norms as food producers and is in line with a renewed focus on increasing food production sustainably.

\section{References}

AHDB. 2015. UK Yearbook 2015 Sheep. Agriculture and Horticulture Development Board, Kenilworth, Warwickshire.

Baginetas, K. 2008. The contested concept of sustainability in agriculture: an examination of the views of policymakers, scientists and farmers. In: Fish, R., Seymour, S., Watkins, C., Steven, M. (Eds.) Sustainable Farmland Management: Transdisciplinary Approaches. CAB International, Wallingford, Oxon, $30-41$.

Boardman, J. 1988. Severe erosion on agricultural land in East Sussex, UK October 1987. Soil Technology 1, 333-348. 
Boardman, J. 1990. Flooding at Pyecombe Golf Course, October 1990. Report for Pyecombe Golf Course.

Boardman, J. 1994. Property damage by run-off from agricultural land. Town and Country Planning 63(9), 249-251.

Boardman, J. 2001. Storms, floods and soil erosion on the South Downs, East Sussex, autumn and winter 2000-01. Geography 86(4), 346-355.

Boardman, J. 2002. The need for soil conservation in Britain - revisited. Area 34(4), 419427.

Boardman, J. 2003. Soil erosion and flooding on the eastern South Downs, southern England, 1976-2001. Transactions Institute British Geographers 28, 176-196.

Boardman, J., Evans, R. 1991. Flooding at Steepdown. Report to Adur District Council.

Boardman, J., Evans, R. 1994. Soil erosion in Britain: a review. In, R.J. Rickson (ed) Conserving Soil Resources: European Perspectives, 3-12, CAB International, Wallingford, UK.

Boardman, J., Evans, R. 2006. Britain. In, Boardman, J., Poesen, J. (eds) Soil Erosion in Europe, Wiley, Chichester, 439-453.

Boardman, J., Robinson, D.A. 1985. Soil erosion, climatic vagary and agricultural change on the Downs around Lewes and Brighton, autumn 1982. Applied Geography 5, 243-258.

Boardman, J., Evans, R., Ford, J. 2003. Muddy floods on the South Downs, southern England: problem and responses. Environmental Science \& Policy 6, 69-83.

Boardman, J., Favis-Mortlock, D. 2014. The significance of drilling date and crop cover with reference to soil erosion by water, with implications for mitigating erosion on agricultural land in South East England. Soil Use and Management 30, 40-47.

Boardman, J., Shepheard, M.L., Walker, E., Foster, I.D.L. 2009. Soil erosion and riskassessment for on- and off-farm impacts: a test case using the Midhurst area, West Sussex, UK. Journal Environmental Management 90, 2578-2588.

Boardman, J., Vandaele, K. 2010. Soil erosion, muddy floods and the need for institutional memory. Area 42, 502-513.

Boatman, N., Ramwell, C., Parry, H., Jones, N., Bishop, J., Gaskell, P., Short, C., Mills, J., Dwyer, J. 2008. A review of environmental benefits from agri-environment schemes. Final Report to LUPG.

Burnside, N.G., Smith, R.F., Waite, S. 2002. Habitat suitability modelling for calcareous grassland restoration on the South Downs, United Kingdom. Journal of Environmental Management 65, 209-221. 
Burton, R.J.F. 2004. Seeing through the 'good farmer's' eyes: towards developing an understanding of the social symbolic value of 'productivist' behaviour. Sociologia Ruralis 44(2), 195-216.

Burton, R.J.F., Kuczera, C., Schwartz, G., 2008. Exploring farmers' cultural resistance to voluntary agri-environmental schemes. Sociologia Ruralis 48(1), 16-37.

CEC. 2006. Establishing a Framework for the Protection of Soil and Amending Directive 200435/EC.

Defra. 2004. Developing Measures to Promote Catchment Sensitive Farming. Defra, London.

Defra. 2005a. Entry Level Stewardship Handbook. Defra, London.

Defra. 2005b. Controlling soil erosion. Department for Environment Food and Rural Affairs, London.

Defra. 2006. Single Payment Scheme: Cross Compliance Soil Protection Review. Defra, London.

Defra. 2010. June Census data. Available via http://www.defra.gov.uk/statistics/files/defrastats-foodfarm-landuselivestock-june-results-nationalparks110721.xls\#'South Downs'!A1 (accessed 6.1.12).

Defra. 2015. The Guide to Cross Compliance in England. Defra, London.

Duff, S.N., Stonehouse, P., Hilts, S.G., Blackburn, D.J. 1991. Soil conservation behaviour and attitudes among Ontario farmers toward alternative government policy responses. Journal of Soil and Water Conservation 46 (3), 215-219.

Duruiheoma, F.I, Burek, C.V., Bonwick, G., Alexander, R. 2015. Farmers' perception of soil: implications for soil conservation and sustainable agriculture in the UK. Global Journal of Agricultural Research 3 (3), 11-24.

EBLEX, 2011. News Release 12.7.11. Global sheep price outlook is strong, says new report. Available via http://www.eblex.org.uk/news/Global-sheep-price-outlook-strong.aspx (accessed 10.1.12).

Emery, S.B., Franks, J.R. 2012.The potential for collaborative agri-environment schemes in England: Can a well-designed collaborative approach address farmers' concerns with current schemes? Journal of Rural Studies 28 (3), 218-231.

Ervin, C.E, Ervin, D.E. 1982. Factors affecting the use of soil conservation practices: hypotheses, evidence and policy implications. Land Economics 58, 277-292.

Environment Agency. 2002. Agriculture and natural resources: benefits, costs and potential solutions. No publication details given. 
Environment Agency. 2014. Catchment Sensitive Farming Evaluation Report - Phases 1 to 3 (2006-2014). CSF Evidence Team Aug 2014. Natural England. Available via http://publications.naturalengland.org.uk/publication/6510716011937792

Evans, R. 1990. Soils at risk of accelerated erosion in England and Wales. Soil Use and Management 6, 125-131.

Evans, R. 1996. Soil Erosion and its Impacts in England and Wales. Friends of the Earth, London.

Evans, R. 2010a. Runoff and soil erosion in arable Britain: changes in perception and policy since 1945. Environmental Science \& Policy 13, 141 - 149.

Evans, R., 2010b. Land use and accelerated soil erosion by water in a small catchment on the South Downs, West Sussex, England - past and present. In: Cowley, D.C., Standring, R.A. Abicht, M.J. (Eds.), Landscapes Through the Lens: Aerial Photographs and Historic Environment, Oxbow Books, Oxford, 129-142.

Evans, R., Boardman, J. 1994. Assessment of water erosion in farmers' fields. In: R.J. Rickson (Ed.), Conserving Soil Resources: European Perspectives, 13-24, CAB International, Wallingford, UK.

Evans, R., Boardman, J. 2003. Curtailment of muddy floods in the Sompting catchment, South Downs, West Sussex, southern England. Soil Use and Management 19, 223-231.

Franks, J.R. 2014. Sustainable intensification: a UK perspective. Food Policy 47, 71-80.

Fullen, M.A. 2003. Soil erosion and conservation in Northern Europe. Progress in Physical Geography 27, 331-358.

Government Office for Science. 2011. The Future of Food and Farming: Challenges and Choices for Global Sustainability. Government Office for Science, London.

Green, G. P., Heffernan, W. D. 1987. Soil erosion and perception of the problem. Journal of Rural Studies 3(2) 151-157.

HM Treasury and Defra. 2005. A Vision for the Common Agricultural Policy. HMT and Defra, London.

Ingram, J., Fry, P., Mathieu, A. 2010. Revealing different understandings of soil held by scientists and farmers in the context of soil protection and management. Land Use Policy $27(1), 51-60$.

Jarvis, M.G., Allen, R.H., Fordham, S.J., Hazelden, J., Moffat, A.J., Strudy, R.J. 1984. Soils and their Use in South East England. Soil Survey of England and Wales, Harpenden.

Knowler, D., Bradshaw, B. 2007. Farmers' adoption of conservation agriculture: a review and synthesis of recent research. Food Policy 32, 25-48. 
Lahmar, R. 2010. Adoption of conservation agriculture in Europe: Lessons of the KASSA project. Land Use Policy 27, 4-10.

Lastra-Bravo, X.B., Hubbard, C., Garrod, G., Tolón-Becerra, A. 2015. What drives farmers' participation in EU agri-environmental schemes?: Results from a qualitative meta-analysis. Environmental Science \& Policy 54, 1-9.

Lobley, M., Potter, C.A. 1998. Environmental Stewardship in UK agriculture: A comparison of the environmentally sensitive area programme and the Countryside Stewardship Scheme in South East England. Geoforum 29, 413-432.

Marks, M.J. 1988. Soil erosion on the South Downs. Progress (ADAS), Lewes.

Montgomery, D.R. 2007. Dirt: The Erosion of Civilizations, University of California Press, Berkeley.

Morgan, G., Reid, C. 2008. The national policy dimension for environmentally sustainable agriculture: a UK perspective. In: Fish, R., Seymour, S., Watkins, C., Steven, M. (Eds.) Sustainable Farmland Management: Transdisciplinary Approaches. CAB International, Wallingford, Oxon, 223-235.

Morgan, R.P.C. 2005. Soil Erosion and Conservation, Third Edition, Blackwell, Oxford.

Morris, C., Potter, C. 1995. Recruiting the new conservationalists: Farmers' adoption of agrienvironmental schemes in the U.K. Journal of Rural Studies 16(1), 51-63.

Natural England. 2010. Entry Level Stewardship, Environmental Stewardship Handbook Third Edition February 2010.

Nowak, P.J. 1987. The adoption of agricultural conservation technologies: economic and diffusion explanations. Rural Sociology 42, 208-220.

Posthumus, H., Morris, J. 2010. Implications of CAP reform for land management and runoff control in England and Wales. Land Use Policy 27, 42 - 50.

Posthumus, H., Deeks, L.K., Fenn, I., Rickson, R.J. 2011. Soil conservation in two English catchments: linking soil management with policies. Land Degradation \& Development 22, 97-110.

Potter, C.A., Lobley, M. 1992. The conservation status and potential of elderly farmers: Results from a survey in England and Wales. Journal of Rural Studies 8, 133-143.

Prager, K., Posthumus, H. 2010. Socio-economic factors influencing farmers' adoption of soil conservation practices in Europe. In Napier, T.L. (Ed.) Human Dimensions of Soil and Water Conservation, Nova Science Publishers, 203-223. 
Robinson, D.A., Blackman, J.D. 1990. Some costs and consequences of soil erosion and flooding around Brighton and Hove, autumn 1987. In: Boardman, J., Foster, I.D.L. Dearing, J.A. (Eds.), Soil Erosion on Agricultural Land, Wiley, Chichester, 369-382.

Rogers, E.M. 1995 Diffusion of Innovations. $4^{\text {th }}$ ed., The Free Press, New York.

Ryan, R.L., Erickson, D.L., de Young, R. 2003. Farmers' motivations for adopting conservation along riparian zones in a Mid-Western agricultural watershed. Journal Environmental Planning and Management 46(1), 19-37.

Rural Payments Agency \& Defra. 2009. Single Payment Scheme, Cross Compliance Guidance for Soil Management.

Schneider, F., Ledermann, T., Fry, P., Rist, S. 2010. Soil conservation in Swiss agriculture Approaching abstract and symbolic meanings in farmers' life-worlds. Land Use Policy 27, 332-339.

Seymour, S., Lowe, P., Ward, N., Clark, J. 1999. Moralizing nature? The National Rivers Authority and new moral imperatives for the rural environment. In: Walford, N., Everitt, J. C. and Napton, D. E. (Eds.) Reshaping the countryside: perceptions and processes of rural change, CABI, Wallingford, 39-56.

Silverman, D. 1993. Interpreting Qualitative Data: Methods for Analysisng Talk, Text and Interaction. Sage Publications, London.

Sinden, J. A., King, D. A. 1990. Adoption of Soil Conservation Measures in Manilla Shire, New South Wales. Review of Marketing and Agricultural Economics 58 (2\&3), 179-192.

Smit, B., Smithers, J. 1992. Adoption of soil conservation practices: an empirical analysis in Ontario, Canada. Land Degradation and Rehabilitation 3 (1), 1-14.

Sobels, J., Curtis, A., Lockie, S. 2001. The role of Landcare group networks in rural Australia: exploring the contribution of social capital. Journal of Rural Studies 17(3), 265276.

Stammers, R., Boardman, J. 1984. Soil erosion and flooding on downland areas. The Surveyor 164, 8-11.

Traoré, N., Landry, R., Amara, N. 1998. On-Farm Adoption of Conservation Practices: The Role of Farm and Farmer Characteristics, Perceptions, and Health Hazards. Land Economics 74 (1), 114-127.

Tsouvalis, J., Seymour, S., Watkins, C. 2000. Exploring knowledge-cultures: precision farming, yield mapping and the expert-farmer interface. Environment and Planning A 32, 908-924. 
Verstraeten, G., Poesen, J., Govers, G., Gillijns, K., Van Rompaey, A., Van Oost, K. 2003. Integrating science, policy and farmers to reduce soil loss and sediment delivery in Flanders, Belgium. Environmental Science \& Policy 6, 95 - 103.

Wauters, E., Bielders, C., Poesen, J., Govers, G., Mathijs, E. 2010. Adoption of soil conservation practices in Belgium: an examination of the theory of planned behaviour in the agri-environmental domain. Land Use Policy 27, 86-94.

Wilson, G. A., Hart, K. 2000. Financial imperative or conservation concern? EU farmers' motivations for participation in voluntary agri-environmental schemes. Environment and Planning A 32(12), 2161-2185.

Winter, M. 2000. Strong policy or weak policy? The environmental impact of the 1992 reforms to the CAP arable regime in Great Britain. Journal of Rural Studies 16, 47-59. 
Figure 1. Map of Study area

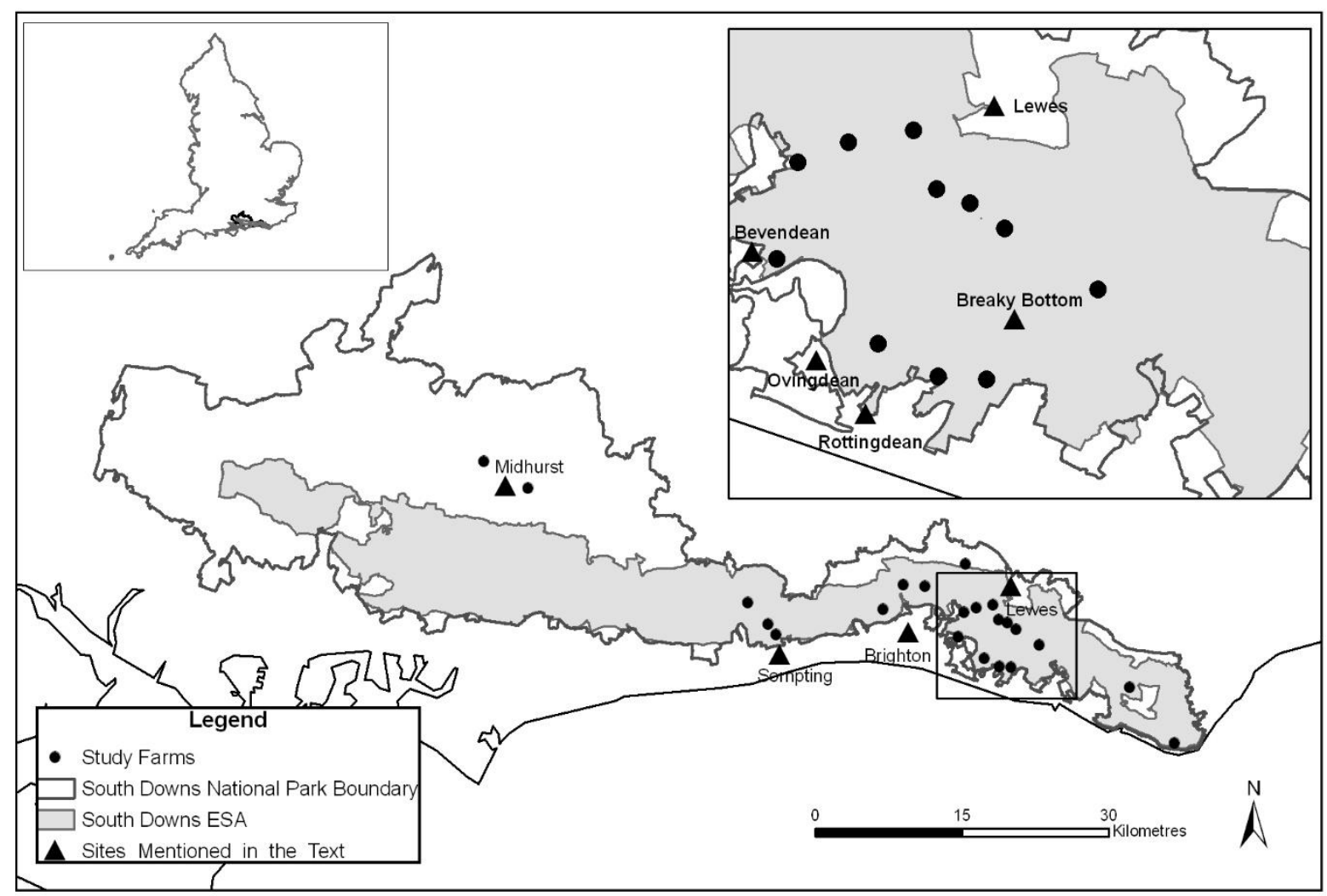


Figure 2a. Erosion on winter cereal field, Rottingdean, 1987

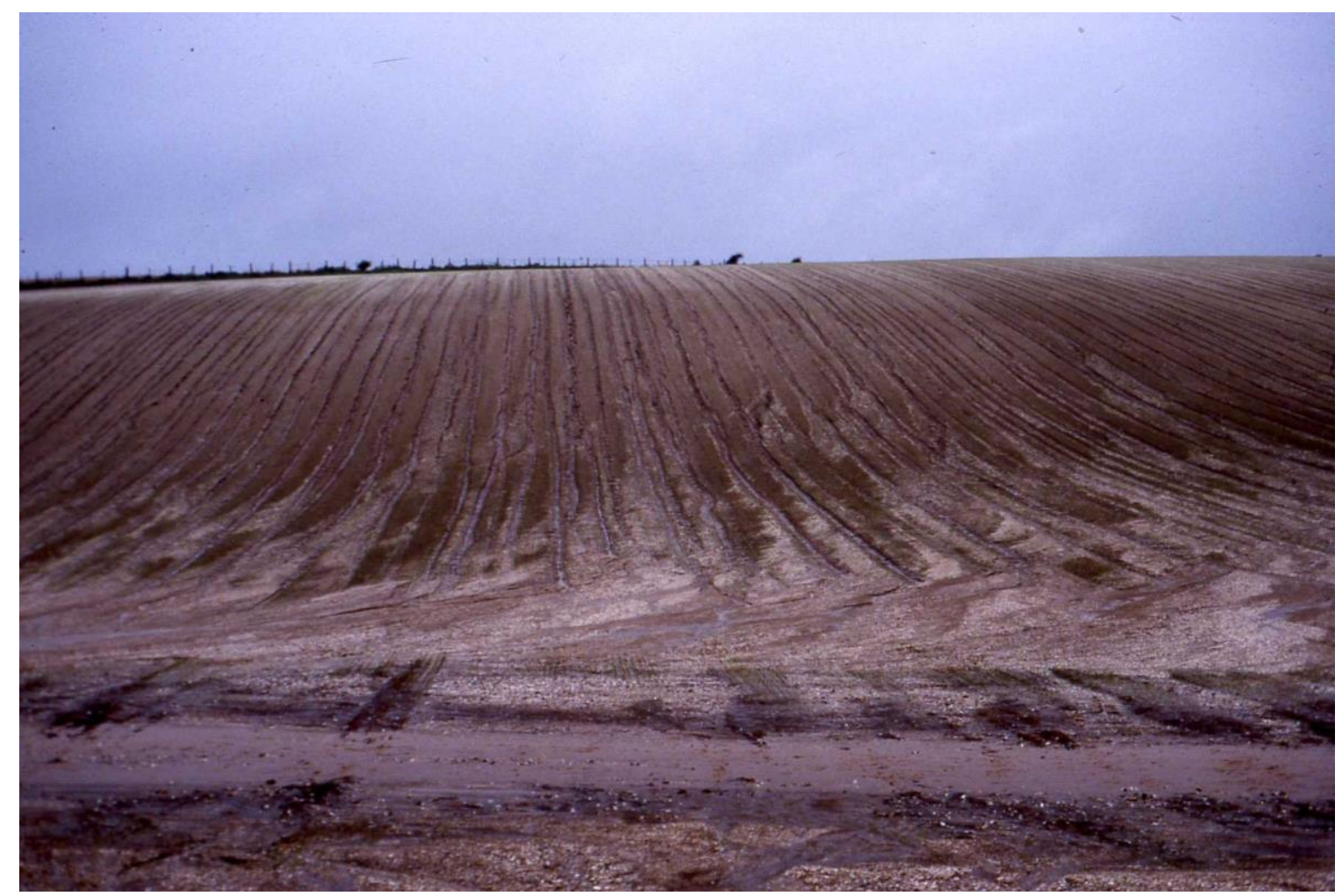

Figure 2b. Off-site flooding from winter cereal field, Lewes, 1991

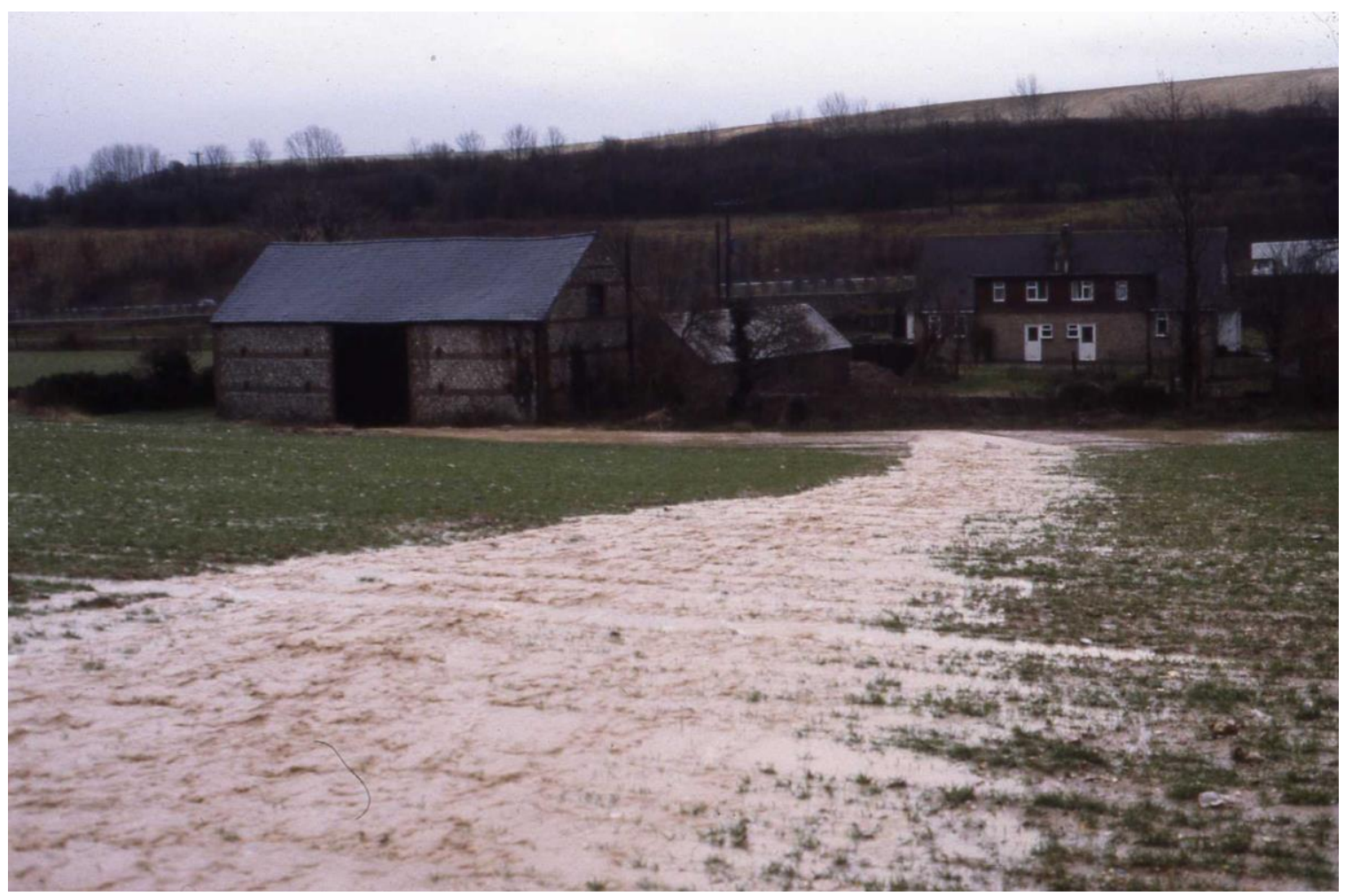


Figure 3. Erosion near Midhurst, 2006

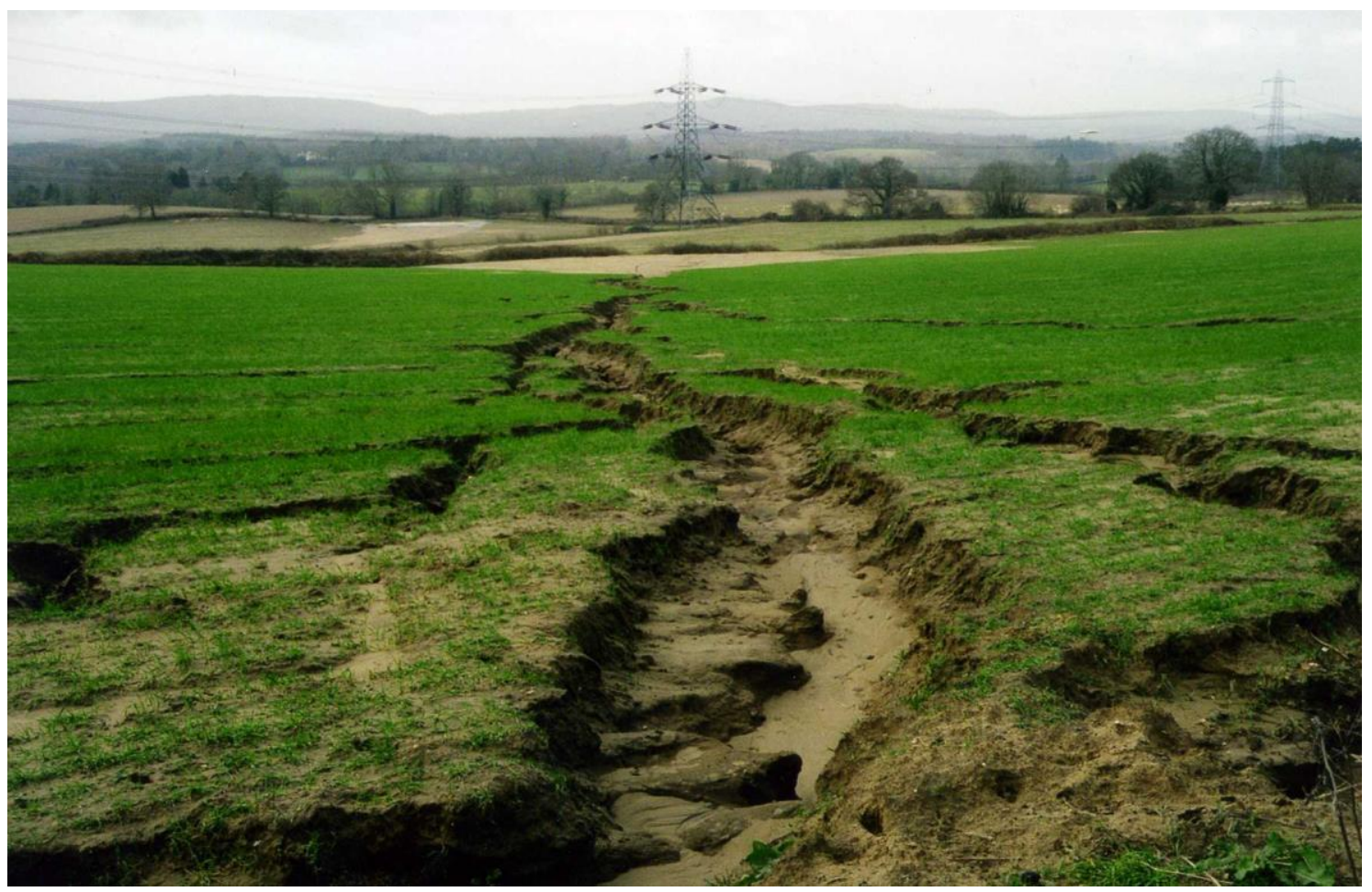

Figure 4. Dam protecting houses, Bevendean, 2000

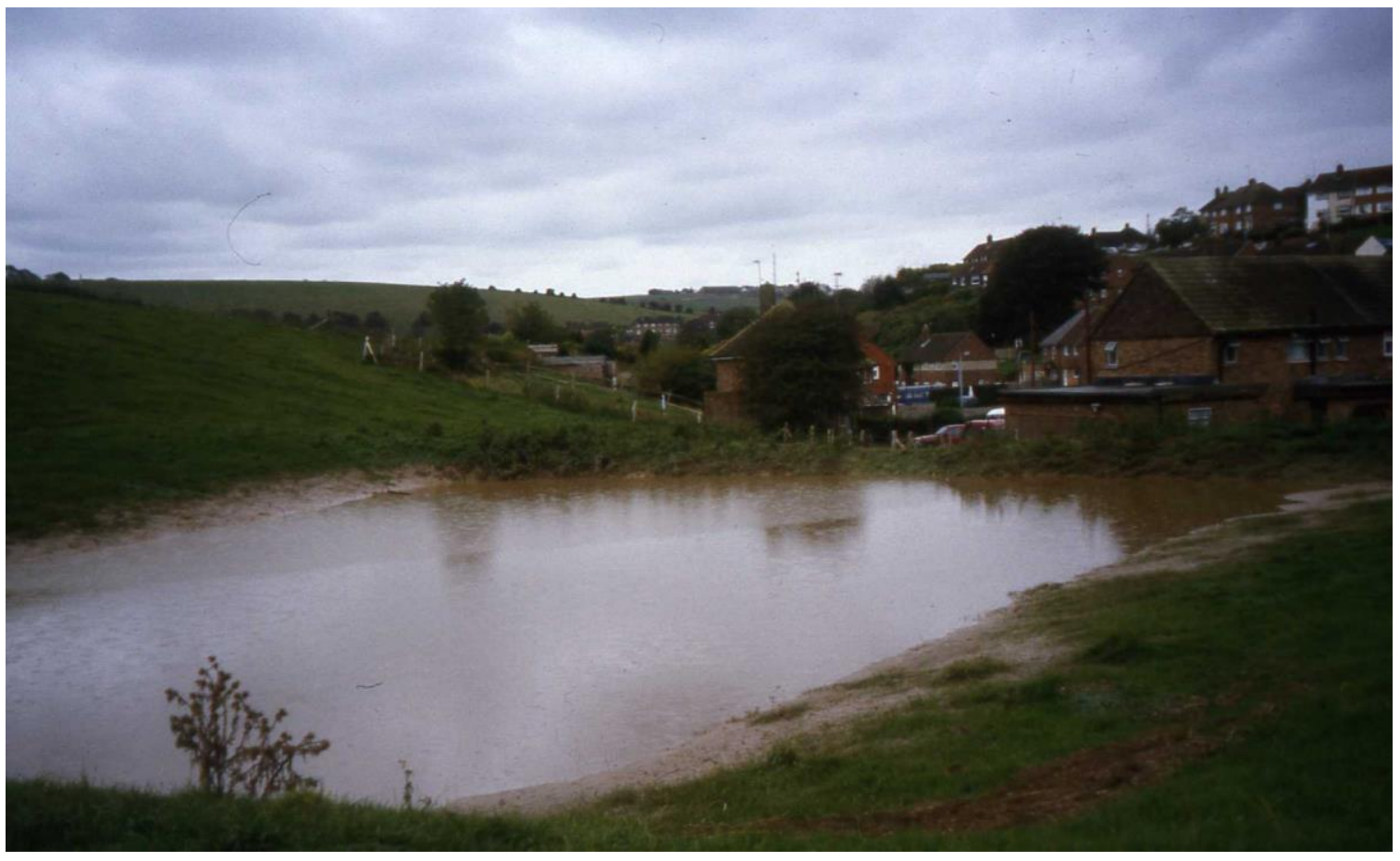


Figure 5. Grass buffer strip, Midhurst, 2006

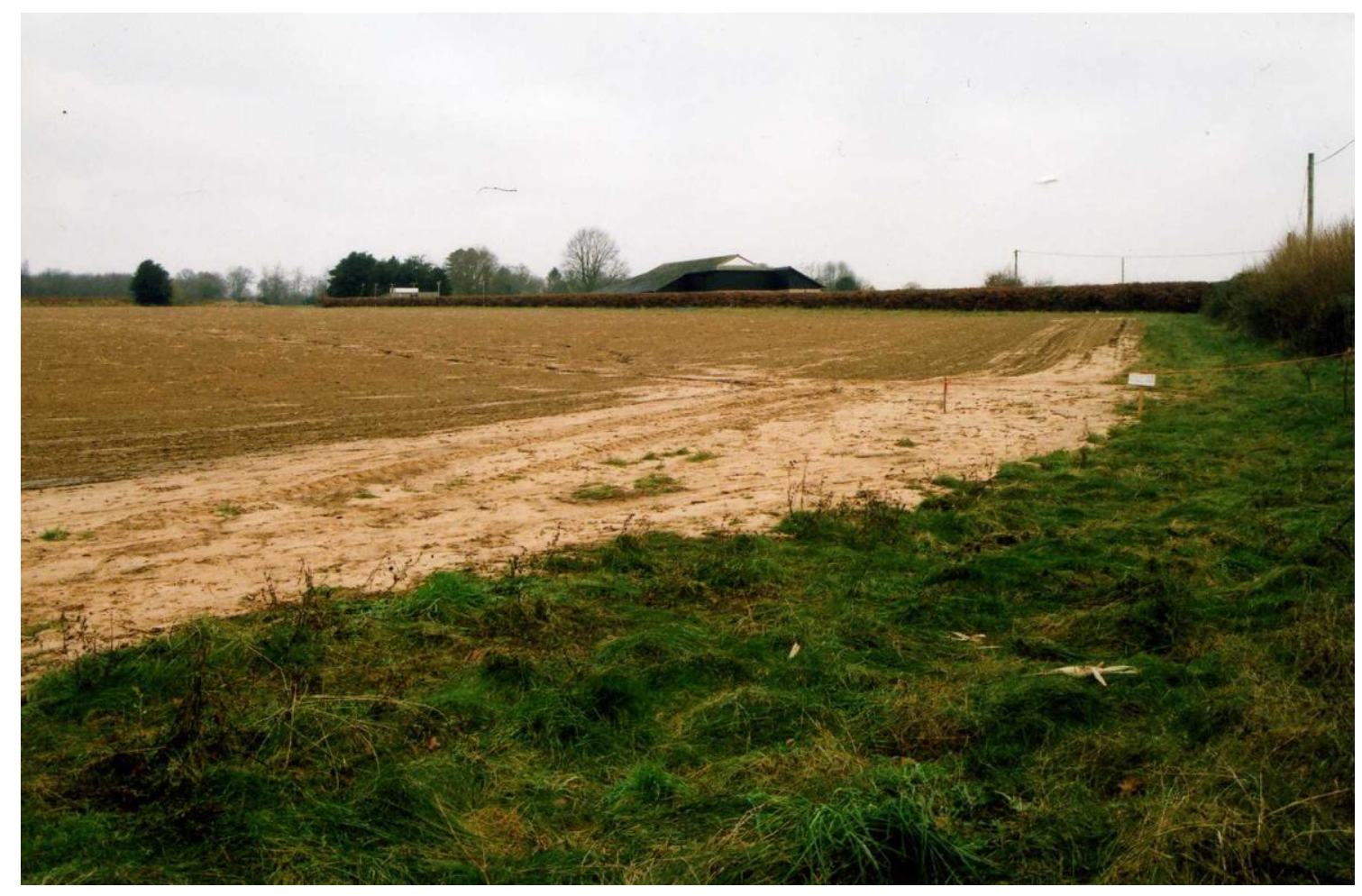


Table 1 Interview themes and questions

\begin{tabular}{|c|c|}
\hline Interview Themes & Questions Asked \\
\hline $\begin{array}{l}\text { General farmer and farm } \\
\text { details }\end{array}$ & $\begin{array}{l}\text { - } \text { Position on the farm } \\
\text { - } \quad \text { Length of time farming there } \\
\text { - } \text { Age group } \\
\text { - } \text { Farm tenancy } \\
\text { - } \text { Main enterprises } \\
\end{array}$ \\
\hline Land use & $\begin{array}{l}\text { - } \text { Current land use of the fields of interest to this research } \\
\text { - } \quad \text { Rotation details (if any) } \\
\text { - How typical current land use/rotation is of the last few years }\end{array}$ \\
\hline $\begin{array}{l}\text { Soil erosion experiences, } \\
\text { impacts and motivations }\end{array}$ & $\begin{array}{l}\text { - Farmers' awareness of serious erosion events on the fields of } \\
\text { interest to this research. } \\
\text { - Farmers' description of these erosion events including any on- and } \\
\text { off-farm impacts. } \\
\text { - What changes (if any) farmers have made to their soil } \\
\text { management practices after these erosion events. } \\
\text { - What motivated farmers to make these changes? } \\
\text { - When these soil management practices were introduced } \\
\text { these particular practices were chosen. }\end{array}$ \\
\hline $\begin{array}{l}\text { Role of agri-environmental } \\
\text { schemes (AES) in soil } \\
\text { conservation and farmer } \\
\text { motivations }\end{array}$ & $\begin{array}{l}\text { - Whether any soil management practices have been carried out } \\
\text { under an AES. } \\
\text { - If so, which soil management practice(s) were chosen. } \\
\text { - The motivation(s) for joining the scheme(s). } \\
\text { - Whether farmers intend to keep the soil management practices in } \\
\text { place for the next } 5 \text { years. }\end{array}$ \\
\hline
\end{tabular}

Table 2 Comparing farm types in the interview sample with those from the 2010 June Census Data

\begin{tabular}{|l|l|l|l|l|}
\hline & Mixed Farms & Livestock Only & Arable Only & Dairy \\
\hline Interview Sample* & $73 \%$ & $14 \%$ & $4 \%$ & $4 \%$ \\
\hline $\begin{array}{l}\text { 2010 June Census } \\
\text { Data }\end{array}$ & $9 \%$ & $42 \%$ & $36 \%$ & $4 \%$ \\
\hline
\end{tabular}

* Farm type figures given here are calculated out of 21 holdings not the entire 22 holdings that were sampled in this study. One set of data is excluded from these figures as the field in question no longer forms part of a farm - it is council owned land and is managed via grazing licences. 
Table 3 Characteristics of soil erosion risk change since erosion events

\begin{tabular}{|c|c|c|c|c|c|c|}
\hline \multirow{2}{*}{$\begin{array}{l}\text { Change in Land Management Practice } \\
\text { Land use change }\end{array}$} & \multicolumn{3}{|c|}{ Number of Fields } & \multicolumn{3}{|c|}{ Percentage of Fields } \\
\hline & $\begin{array}{l}\text { South } \\
\text { Downs } \\
(n=59)\end{array}$ & $\begin{array}{l}\text { Midhurst } \\
(n=7)\end{array}$ & $\begin{array}{l}\text { Whole } \\
\text { Study } \\
\text { Area } \\
(n=66)\end{array}$ & $\begin{array}{l}\text { South } \\
\text { Downs }\end{array}$ & Midhurst & $\begin{array}{l}\text { Whole } \\
\text { Study } \\
\text { Area }\end{array}$ \\
\hline Arable reversion to permanent grassland*† & $27 * *$ & 1 & 28 & 46 & 14 & 42 \\
\hline Overwinter stubble $†$ & 15 & 5 & 20 & 25 & 71 & 30 \\
\hline Buffer stripst & 4 & 2 & 6 & 7 & 29 & 9 \\
\hline Beetle banks ${ }^{\dagger}$ & 5 & 0 & 5 & 8 & 0 & 8 \\
\hline \multicolumn{7}{|l|}{ Change in cultivation techniques } \\
\hline Works across slope & 29 & 5 & 34 & 49 & 71 & 52 \\
\hline Minimum tillage & 18 & 2 & 20 & 31 & 29 & 30 \\
\hline Timing of operations (ploughing, sowing etc) & 17 & 7 & 24 & 29 & 100 & 33 \\
\hline Adds organic matter & 5 & 5 & 10 & 8 & 71 & 15 \\
\hline Avoids compaction on headlands & 0 & 5 & 5 & 0 & 71 & 8 \\
\hline Leaves seedbeds rough & 0 & 5 & 5 & 0 & 71 & 8 \\
\hline Doesn't roll & 0 & 5 & 5 & 0 & 71 & 8 \\
\hline Changed roller & 3 & 0 & 3 & 5 & 0 & 5 \\
\hline Rolls & 1 & 0 & 1 & 2 & 0 & 2 \\
\hline Change in cropping patterns $* * *$ & 15 & 5 & 20 & 25 & 71 & 23 \\
\hline Earthworks built or modernized* & 10 & 0 & 10 & 17 & 0 & 15 \\
\hline
\end{tabular}

* Some arable reversion ( 6 fields, all South Downs) and earthwork construction/modernization ( 8 fields) was carried out by previous land managers and not the interviewee.

** One response was from an agent who confirmed that arable reversion had been undertaken on one field owned by Eastbourne Borough Council.

*** Change in cropping patterns: splits fields with different crops and/or ensures there are different crops in adjacent fields on sloping ground or has broken up arable monoculture with buffer strips, beetle banks, arable reversion.

† Practices which potentially (directly or indirectly) decrease erosion risk and which are supported through agrienvironment scheme measures and information/advice. 
Table 4 Reasons for soil erosion risk change

\begin{tabular}{|c|c|c|c|c|c|c|c|c|c|c|c|}
\hline & Erosion & Economics & $\begin{array}{l}\text { Landlord } \\
\text { Pressure }\end{array}$ & $\begin{array}{l}\text { Insurance } \\
\text { Company } \\
\text { Pressure }\end{array}$ & $\begin{array}{l}\text { Nature } \\
\text { Conservation }\end{array}$ & $\begin{array}{l}\text { Poor/ } \\
\text { Difficult } \\
\text { Land }\end{array}$ & Logistics & Livestock & $\begin{array}{l}\text { Public } \\
\text { Access }\end{array}$ & $\begin{array}{l}\text { Improved } \\
\text { Machinery }\end{array}$ & $\begin{array}{l}\text { No Arable } \\
\text { Infrastructure }\end{array}$ \\
\hline F1 & $A R$ & $A R$ & & & & & $A R$ & $A R$ & & & \\
\hline F2 (Md) & $\begin{array}{l}\text { AR, OWS, BS, } \\
\text { WAS, TO, } \\
\text { AOM, DNR, } \\
\text { AC, LSR, CCP }\end{array}$ & & & & & & & & & & \\
\hline F3 & TO & AR, OWS & & & & & & & & & \\
\hline F4 & $\begin{array}{l}\text { OWS, WAS, } \\
\text { AOM, CCP }\end{array}$ & OWS & & & & & & & & & \\
\hline F5 & CR & & & & & & & & & & \\
\hline F6 & WAS & OWS & & & & & & & & WAS & \\
\hline F7 & $\begin{array}{l}A R, O W S, C C P, \\
B S, B B\end{array}$ & OWS, BB & & & BB & & & & & & \\
\hline F8 & $\begin{array}{l}\text { AR, WAS, MT, } \\
\text { CCP, TO }\end{array}$ & & & TO & & & & & & & \\
\hline F9 & WAS & $\mathrm{AR}, \mathrm{MT}$ & & & & & & & & & \\
\hline
\end{tabular}




\begin{tabular}{|c|c|c|c|c|c|c|c|c|c|c|}
\hline F10 & $\begin{array}{l}\text { WAS, CR, (AR), } \\
\text { (EW) }\end{array}$ & $(A R)$ & (AR) & & (AR) & (AR) & & & WAS & \\
\hline F11 & & $A R$ & & & & AR & $A R$ & & & \\
\hline F12 & EW & & & & $A R$ & & $A R$ & & & \\
\hline F13 & & $A R$ & & & & & & & & $A R$ \\
\hline F14 (Md) & MT, TO & & & & & & & & & \\
\hline F15 & $\begin{array}{l}\text { OWS, WAS, } \\
\text { TO, R }\end{array}$ & OWS & & OWS & $A R$ & & & & WAS & \\
\hline F16 & (AR) & & (AR) & & & & & (AR) & & \\
\hline F17 & $A R$ & AR & & & & & & & & \\
\hline F18 & WAS, TO & & $A R$ & & & & & $A R$ & & \\
\hline F19* & & & & & & & & & & \\
\hline F20** & & (AR) & & & & & & (AR) & & \\
\hline F21 & (AR), (EW) & & & & & & & & & \\
\hline
\end{tabular}


Table 5 Influence of on- and off-farm impacts of erosion on farmers' management practices

\begin{tabular}{|c|c|c|c|c|c|c|c|c|c|c|}
\hline \multirow[b]{2}{*}{ Farmer ID } & \multirow[b]{2}{*}{$\begin{array}{l}\text { Changes in } \\
\text { Management } \\
\text { Practices Since } \\
\text { Erosion }\end{array}$} & \multicolumn{5}{|c|}{ On-farm Impacts } & \multicolumn{4}{|c|}{ Off-farm Impacts } \\
\hline & & $\begin{array}{l}\text { Rills/ } \\
\text { Gullies }\end{array}$ & $\begin{array}{l}\text { Soil on } \\
\text { Paths/ } \\
\text { Tracks }\end{array}$ & $\begin{array}{l}\text { Soil/ } \\
\text { Water } \\
\text { on } \\
\text { Farm }\end{array}$ & $\begin{array}{l}\text { Soil/ } \\
\text { Fertility } \\
\text { Loss }\end{array}$ & Inconvenience & $\begin{array}{l}\text { Soil/Water } \\
\text { on Roads }\end{array}$ & $\begin{array}{l}\text { Soil in } \\
\text { Rivers }\end{array}$ & $\begin{array}{l}\text { Soil/Water } \\
\text { on Other's } \\
\text { Property }\end{array}$ & Farmers' Personal Experience of Erosion \\
\hline F1 (SD) & $A R^{*}$ & & Yes & & & & & & & Soil on farm footpath/bridleway. \\
\hline F2 (Md) & $\begin{array}{l}\text { AR, OWS, BS, } \\
\text { WAS, TO, AOM, } \\
\text { DNR, AC, LSR, } \\
\text { CCP }\end{array}$ & Yes & & & Yes & Yes & Yes & Yes & & $\begin{array}{l}\text { Deep soil on road. Gullies in fields which } \\
\text { farmer filled in but soil had lost fertility } \\
\text { and was like "washed sand". Some soil } \\
\text { lost to River Rother. }\end{array}$ \\
\hline F3 (SD) & $\begin{array}{l}\mathrm{AR}^{* *}, \mathrm{OWS} \mathrm{S}^{* *}, \\
\text { TO }\end{array}$ & Yes & & Yes & & & Yes & & & $\begin{array}{l}\text { Had } 4 \text { foot gully and smaller rills. Soil and } \\
\text { water flowed through the farm. Has had } \\
\text { water go onto road. }\end{array}$ \\
\hline F4 (SD) & $\begin{array}{l}\text { OWS*, WAS, } \\
\text { AOM, CCP }\end{array}$ & Yes & & Yes & Yes & & Yes & & Yes & $\begin{array}{l}\text { Rill erosion in valley and large gully in } \\
\text { valley bottom. Soil on nearby road and } \\
\text { gardens. Soil and water flowed through } \\
\text { farm yard. }\end{array}$ \\
\hline F6 (SD) & WAS*, OWS** & Yes & & & & Yes & & & & Eroded soil was moved to fill in gullies. \\
\hline F7 (SD) & $\begin{array}{l}\text { AR, CCP, BS, } \\
\text { OWS*, BB* }\end{array}$ & Yes & & & Yes & & & & Yes & $\begin{array}{l}\text { There was "a huge amount of erosion" } \\
\text { which flowed into nearby town. Two } \\
\text { farm cottages also flooded. Had 6ft gully }\end{array}$ \\
\hline
\end{tabular}




\begin{tabular}{|c|c|c|c|c|c|c|c|c|}
\hline & & & & & & & & $\begin{array}{l}\text { in one field. Eroded adjacent farmland } \\
\text { too. }\end{array}$ \\
\hline F8 (SD) & $\begin{array}{l}\text { AR, WAS, MT, } \\
\text { TO*, CCP }\end{array}$ & Yes & & Yes & & & Yes & $\begin{array}{l}\text { Gullies and large amount of runoff on } \\
\text { several fields resulting in flooding of } \\
\text { neighbouring property. }\end{array}$ \\
\hline F9 (SD) & $\begin{array}{l}\text { WAS, AR**, } \\
\text { MT** }\end{array}$ & Yes & & Yes & Yes & & Yes & $\begin{array}{l}\text { Large amount of soil washed onto nearby } \\
\text { golf course. }\end{array}$ \\
\hline F12 (SD) & $\mathrm{EW}, \mathrm{AR}^{* *}$ & Yes & Yes & & & Yes & Yes & $\begin{array}{l}\text { Main road was } 3 \text { feet deep in water. } \\
\text { Muddy floods in nearby properties. }\end{array}$ \\
\hline F14 (Md) & $\mathrm{MT}, \mathrm{TO}$ & Yes & & Yes & Yes & & & $\begin{array}{l}\text { Erosion caused gullies which he had to } \\
\text { work around. Soil loss in one field, silt } \\
\text { deposited on adjacent field affecting } \\
\text { fertility in both. }\end{array}$ \\
\hline F15 (SD) & $\begin{array}{l}\text { TO, R, OWS*, } \\
\text { WAS*, AR** }\end{array}$ & Yes & & & & & & $\begin{array}{l}\text { Erosion caused gullies in a valley within } \\
\text { the field which were taken out by } \\
\text { working the field. He didn't think the } \\
\text { impact was too bad. }\end{array}$ \\
\hline
\end{tabular}

